\title{
EDUKASI PERPAJAKAN MELALUI PEMBELAJARAN MATA KULIAH PENDIDIKAN PANCASILA DAN KEWARGANEGARAAN
}

\author{
Hasbi $\mathrm{Ali}^{1}$ \\ Indra Keusuma Hadi ${ }^{2}$ \\ ${ }^{1}$ Jurusan PPKn FKIP USK, Banda Aceh, Indonesia \\ ${ }^{2}$ Fakultas Hukum USK, Banda Aceh, Indonesia \\ Email: asbysagita@yahoo.co.id \\ indrakesumahadi@unsyiah.ac.id
}

\begin{abstract}
ABSTRAK
Kesadaran pajak oleh warganegara ini perlu diedukasi sedemikian rupa, terutama melalui institusi pendidikan. Hal ini dimungkinkan karena salah satu fungsi pajak adalah untuk penyediaan fasilitas pendidikan yang memadai. Dalam hal ini, pasal 3 Undang Undang Dasar Republik Indonesia Tahun 1945 bahwa "Pendidikan nasional berfungsi mengembangkan kemampuan dan membentuk watak serta peradaban bangsa yang bermartabat dalam rangka mencerdaskan kehidupan bangsa bertujuan untuk berkembangnya potensi peserta didik agar menjadi manusia yang beriman dan bertakwa kepada Tuhan Yang Maha Esa, berakhlak mulia, sehat, berilmu, cakap, kreatif, mandiri, dan menjadi warganegara yang demokratis serta bertanggungjawab". Tulisan tentang edukasi kesadaran pajak ini selain sebagai sumbangan pemikiran teoritis dalam khasanah ilmu pengetahuan terkait dengan perpajakan secara umum, secara khusus tulisan ini bertujuan untuk: (1) Memberikan pengetahuan tentang hak dan kewajiban warganegara, (2) Memberikan pengetahuan tentang kesadaran hukum warganegara, dan (3) Memberikan pengetahuan tentang kesadaran untuk membayar pajak warganegara. Edukasi kesadaran pajak dapat dibelajarkan melalui mata kuliah Pendidikan Pancasila dan Kewarganegaraan (PPKn) karena tujuannya adalah menanamkan pengetahuan kewarganegaraan (civic knowledge), sikap kewarganegaraan (civic disposition), dan keterampilan kewarganegaraan (civic skills). Kesadaran membayar pajak dari warganegara ini sangat ditentukan oleh kesadaran hukumnya, sehingga warga negara menaatinya. Kesadaran pajak ini perlu terus ditumbuhkembangkan, terutama kepada generasi muda (mahasiswa) sebagai pemegang estafet pembangunan nasional yang berkelanjutan (sustainable development). Dimana, pajak yang dipungut merupakan devisa negara yang akan digunakan untuk pembiayaan pembangunan nasional.
\end{abstract}

Kata kunci: Edukasi Perpajakan, Pembelajaran Pendidikan Kewarganegaraan. 


\section{PENDAHULUAN}

Pajak merupakan salah satu sumber pendapatan negara dalam menunjang pelaksanaan pembangunan nasional yang berkelanjutan (sustainable national development). Dimana, pembangunan nasional berupaya untuk mewujudkan kesejahteraan rakyat secara komunal sebagaimana tujuan negara yang termuat dalam Alenia Keempat Pembukaan Undang Undang Dasar Republik Indonesia bahwa negara hendak "memajukan kesejahteraan umum". Namun demikian, realitas menunjukkan bahwa masih banyak warganegara yang belum menyadari tenatng urgensi dari membayar pajak kepada negara. Padahal, kewajiban warganegara ini dapat dipaksakan pelaksanaannya oleh negara sebagaimana diamanatkan pasal 23 A Undang Undang Dasar Republik Indonesia Tahun 1945 bahwa "Pajak dan pungutan lain yang bersifat memaksa untuk keperluan negara diatur dengan undang- undang”.

Kesadaran pajak oleh warganegara ini perlu diedukasi sedemikian rupa, terutama melalui institusi pendidikan. Hal ini dimungkinkan karena salah satu fungsi pajak adalah untuk penyediaan fasilitas pendidikan yang memadai. Dalam hal ini, pasal 3 Undang Undang Dasar Republik Indonesia Tahun 1945 bahwa "Pendidikan nasional berfungsi mengembangkan kemampuan dan membentuk watak serta peradaban bangsa yang bermartabat dalam rangka mencerdaskan kehidupan bangsa bertujuan untuk berkembangnya potensi peserta didik agar menjadi manusia yang beriman dan bertakwa kepada Tuhan Yang Maha Esa, berakhlak mulia, sehat, berilmu, cakap, kreatif, mandiri, dan menjadi warganegara yang demokratis serta bertanggungjawab".

Edukasi pajak ini dapat diintegrasikan melalui berbagai mata kuliah yang terkait, salah satunya adalah Pendidikan Kewarganegaraan (PKn) di Perguruan Tinggi. Matakuliah Pendidikan Pancasila dan Kewarganegaraan (PPKn) merupakan salah satu Mata Kuliah Wajib Umum (MKWU) di Perguruan Tinggi yang bertujuan untuk membentuk karakter bangsa. Materi Pendidikan Pancasila dan Kewarganegaraan (PPKn) di Perguruan Tinggi banyak disinggung tentang kesadaran pajak warganegara sebagai amanah dari Direktorat Pajak dan Keuangan untk menguatkan kesadaran pajak pada mahsiswa sebagai bagian yang tidak terpisahkan dari warganegara. Oleh karena itu, Mata Kuliah Wajib Umum (MKWU) Pendidikan Pancasila dan Kewarganegaraan (PPKn) di Perguruan Tinggi memiliki posisi yang sangat strategis dalam melakukan transfer ilmu pengetahuan dan sekaligus mentansformasi nilai- nilai karakter bangsa kepada mahasiswa.

Pendidikan Pancasila dan Kewarganegaraan (PPKn) secara eksplisit bertujuan untuk membentuk karakter warganegara yang sesuai dengan nilai- nilai luhur Pancasila. Dimana, Pendidikan Pancasila dan Kewarganegaraan (PPKn) bertujuan untuk memberikan pengetahuan kenegaraan kepada warganegara (civic knowledge), menanamkan sikap kenegaraan (civic disposition), dan keterampilan kenegaraan bagi warganegara (civic skills). Terkait dengan edukasi kesadaran pajak ini, Pendidikan Pancasila dan Kewarganegaraan (PPKn) menanamkan kesadaran warganegara tentang hak dan kewajibannya yang harus dipahami oleh mahasiswa sebagai generasi penerus bangsa. Materi- materi yang diajarkan dalam proses perkuliahan Pendidikan Pancasila dan Kewarganegaraan (PPKn) terkait dengan hak dan kewajiban warganegara serta kesadaran hukum warganegara.

\section{METODE PENELITIAN \\ Hak dan Kewajiban Warganegara}

Manusia sebagai makhluk yang lemah dan memiliki keterbatasan tidak selamanya mampu melaksanakan hak dan kewajibannya secara sempurna. Oleh 
karena itu, dalam kapasitasnya sebagai warganegara juga manusia sering lalai dalam melaksanakan hak dan kewajibannya. Disadari bahwa hak merupakan drivat dari kewajiban, dimana antara hak dan kewajiban warganegara bagai dua sisi mata uang yang saling melengkapi dan ketergantungan antara satu dengan lainnya. Secara umum hak warga negara dimaksudkan sebagai suatu kewenangan yang dimiliki oleh warga negara guna melakukan sesuatu sesuai peraturan perundangundangan. Sedangkan kewajiban warga negara Dimaksudkan adalah suatu keharusan yang tidak boleh ditinggalkan oleh warga negara dalam kehidupan bermasyarkat berbangsa dan bernegara.

Dalam hal ini, persoalan yang paling mendasar terkait dengan hubungan antara negara dan warganegara adalah masalah hak dan kewajiban. Negara, demikian pula warganegara sama- sama memiliki hak dan kewajiban masing- masing. Sesungguhnya dua hal ini saling terkait karena berbicara hak negara berarti berbicara tentang kewajiban warganegara, demikian pula sebaliknya berbicara kewajiban negara adalah berbicara tentang hak warganegara. Kesadaran akan hak dan kewajiban sangatlah penting, seseorang yang semestinya memiliki hak namun ia tidak menyadarinya, maka akan membuka peluang bagi pihak lain untuk menyimpangkannya. Demikian pula sebaliknya, ketidaksadaran seseorang akan kewajibannya akan membuat hak yang semestinya didapatkan orang lain menjadi dilanggar atau diabaikan.

Menurut Notonagoro dalam Dirjen Belmawa (2016:132) menjelaskan bahwa hak adalah kuasa untuk menerima atau melakukan suatu yang semestinya diterima atau dilakukan oleh pihak tertentu dan tidak dapat oleh pihak lain mana pun juga yang pada prinsipnya dapat dituntut secara paksa olehnya. Wajib adalah beban untuk memberikan sesuatu yang semestinya dibiarkan atau diberikan oleh pihak tertentu tidak dapat oleh pihak lain mana pun yang pada prinsipnya dapat dituntut secara paksa oleh yang berkepentingan. Kewajiban dengan demikian merupakan sesuatu yang harus dilakukan. Hak dan kewajiban harus dlaksanakan secara seimbang (resiplokalitas), sehingga tercapainya tujuan yang diharapkan. Apabila terjadi ketimpangan dalam pelaksanaannya, mengakibatkan salah satu bagian tidak terpenuhi secara maksimal.

Hak warga negara adalah suatu kewenangan yang dimiliki oleh warga negara guna melakukan sesuatu sesuai peraturan perundangundangan. Dengan kata lain hak warga negara merupakan suatu keistimewaan yan menghendaki agar warga negara diperlakukan sesuai keistimewaan tersebut. Sedangkan Kewajiban warga negara adalah suatu keharusan yang tidak boleh ditinggalkan oleh warga negara dalam kehidupan bermasyarkat berbangsa dan bernegara. Kewajiban warga negara dapat pula diartikan sebagai suatu sikap atau tindakan yang harus diperbuat oleh seseorang warga negara sesuai keistimewaan yang ada pada warga lainnya.

\subsection{Kesadaran Hukum Warganegara}

Cita- cita Negara Kesatuan Republik Indonesia sebagaimana tercantum dalam Pembukaan Undang Undang Dasar Republik Indonesia Tahun 1945 bahwa negara ingin mewujudkan masyarakat adil dan makmur, baik materil maupun sprituil. Oleh karena itu, pemerintah mengharapkan adanya kesadaran hukum dari masyarakat agar berbagai kebijakan pembangunan dapat terlaksana secara maksimal. Dalam hal ini, Ali Yuswandi (1995:1) mengatakan bahwa "Pembangunan di bidang hukum merupakan salah satu yang tidak terpisahkan dari pembangunan manusia seutuhnya agar terwujudnya masyarakat yang sadar hukum. Disadari bahwa pembangunan di bidang hukum merupakan salah satu prasarana untuk mewujudkan 
sistem dan produk hukum yang dapat memberikan pengayoman dan landasan hukum, baik kepada masyarakat maupun pembangunan".

Indonesia merupakan negara hukum sebagaimana dinyatakan dalam pasal 1 ayat (3) Undang Undang Dasar Republik Indonesia Tahun 1945 bahwa "Indonesia adalah negara hukum". Konsekuensi dari ditetapkannya negara kita adalah negara hukum adalah dalam segala kehidupan bermasyarakat maupun bernegara selalu berdasarkan kepada hukum. Oleh karena itu, kewajiban warga negara adalah menampilkan sikap positif terhadap semua hukum yang berlaku baik dalam kehiudpan bermasyarakat maupun kehidupa bernegara. Namun demikian, masyarakat masih ada yang belum sadar hukum. Hal ini dapat disebabkan oleh banyak faktor, baik internal maupun eksternal.

Kesadaran hukum masyarakat dapat dilihat dalam dua konteks pengertian, yaitu secara sempit dan luas. Kesdaran hukum masyarakat dalam arti sempit dimaknai sebagai pengetahuan tentang perintah dan larangan tindakan hukum tertentu, sedangkan dalam arti luas dimaknai kemantapan hati untuk mematuhi segala peraturan hukum yang berlaku (kesadaran afeksi). Oleh karena itu, menurut Esmi Warassih (2005:114-115) bahwa "Kesadaran hukum tidak tumbuh dan berkembang begitu saja dalam hati nurani masyarakat, akan tetapi merupakan sesuatu yang harus dipupuk secara sadar agar dapat tumbuh dan berkembang dalam hati sanubari masyarakat".

Dalam konsep negara hukum, hukum harus memiliki supremasi. Supremasi hukum ini terlihat dari indikator::

1. Ketaatan terhadap peraturan perundangundangan yang didesain sebagai payung hukum bagi semua warganegara.

2. Kedisiplinan para pemimpin negara serta penyelenggara negara pada semua level dalam melaksanakan kebijakan yang dilandasi ketaatan pada hukum yang melekat pada dirinya, sehingga penyalahgunaan

penyelewengan kewajiban, atau pembelokan tujuan bisa ditekan sekecilkecilnya.

3. Hukum yang diciptakan benar- benar hukum yang bersendikan keadilan dan ketertiban serta manfaat bagi semua warganya, sehingga memancarkan kewibawaan dan perlindungan kepada setiap manusia (Ilham Bisri, 2004:129130).

Oleh karena itu, dalam upaya meningkatkan kesadaran hukum masyarakat tidak perlu dengan tindakan represif, misalnya memperberat ancaman atau memaksakan ketaatan warganegara terhadap peraturan yang berlaku. Akan tetapi, biarlah kesadaran hukum masyarakat tersebut lahir dari perasaan hukum mereka sendiri. Mewujudkan kesadaran hukum masyarakat, diperlukan adanya pembenahan di berbagai aspek seperti substansi hukum (peraturan perundangundangan) yang kurang responsif, peraturan perundang- undangan yang tumpang tindih, kerancuan hukum, masih kurangnya sarana dan prasarana hukum, masih sangat terbatasnya integritas dan profesionalisme aparat penegak hukum, kesadaran hukum masyarakat, mutu pelayanan hukum, serta kepastian dan keadilan hukum yang mengakibatkan penegakan prinsip- prinsip negara hukum belum dapat diwujudkan secara optimal (Atang Hermawan Usman, 2014:;27).

Membangun agar tumbuhnya kesadaran hukum masyarakat ini berkonsekuensi logis terhadap perilaku hukum, seperti:

1. Kesadaran hukum masyarakat mengenai peristiwa- peristiwa tertentu tidak sejalan dengan kesadaran hukum para pejabat hukum.

2. Kesadaran hukum atau pola perilaku masyarakat mengenai peristiwaperistiwa tertentu belum sejalan dengan ketentuan- ketentuan hukum yang tertulis, terutama mengenai kepastian hukum dan ketertiban umum. 
3. Kesadaran hukum para pejabat belum sejalan dengan ketentuan- ketentuan hukum yang tertulis. (Soerjono Soekanto, 2005:167).

Oleh karena itu, upaya untuk meningkatkan kesadaran hukum masyarakat diperlukan adanya sosialisasi agar terbinanya masyarakat sadar hukum seperti polisi masuk desa, jaksa masuk desa, hakim masuk desa, dan bentul lainnya. Kesadaran hukum ini diperlukan agar masyarakat memahami akan hak dan kewajibannya baik sebagai individu, anggota masyarakat, maupun warganegara. Kesadaran hukum dalam hal ini dimaksudkan adalah suatu pengejewantahan nilai- nilai yang ada di dalam diri individu baik hukum positif (constitutum) maupun hukum masa depan (constituendum). Tumbuh kembangnya kesadaran hukum masyarakat ini sangat ditentukan oleh banyak faktor, baik internal maupun eksternal. Beberapa faktor tersebut, antara lain:

1. Compiliance, dimana merupakan suatu bentuk kepatuhan yang didasarkan pada harapan akan suatu imbalan dan usaha untuk menghindarkan diri dari hukuman atau sanksi yang mungkin dikenakan apabila seseorang melanggar ketentuan hukum.

2. Identification, dimana hanya mungkin terjadi apabila kepatuhan terhadap hukum tidak didasari nilai instrinsik semata, melainkan untuk menjaga ketertiban masyarakat itu sendiri.

3. Internalization, dimana pennanaman kepatuhan terhadap hukum agar munculnya kepercayaan masyarakat terhadap kebenaran hukum yang diterapkan. Internalisasi diperlukan agar kepatuhan terhadap hukum nantinya menjadi keseharian warga negara.

4. Culturalized, dimana kepatuhan terhadap hukum hanya akan dapat membudaya dalam keseharian masyarakat apabila substansi hukum tersebut berkaitan erat dengan kepentingan- kepentingan masyarakat itu sendiri (Soerjono Soekanto, 2005:167).

Keempat kondisi yang digambarkan di atas berkaitan erat dengan kepatuhan masyarakat terhadap hukum yang tentu saja terlebih dahulu didasari oleh telah tumbuh dan berkembangnya kesadaran hukum masyarakat. Hal ini dimungkinkan karena diketahui bahwa kesadaran hukum merupakan suatu penilaian terhadap hukum yang ada dan hukum yang akan ada (dicitacitakan). Muncul tidaknya kesadaran hukum pada masyarakat dapat diukur dari sejumlah indikatornya, dimana antara satu dengan lainnya saling mengkualifikasi, yaitu: (1) Pengetahuan hukum, (2) Pemahaman hukum, (3) Sikap hukum, dan (4) Pola perilaku hukum.

Kesadaran hukum berperan sangat penting dalam penegakan hukum, artinya semakin lemah tingkat kesadaran hukum masyarakat, semakin lemah pula ketatan hukumnya sebaliknya semakin kuat kesadaran hukumnya semakin kuat pula faktor ketaatan hukum. Kesadaran hukum masyarakat yang pada gilirannya akan menciptakan suasana penegakan hukum yang baik, yang dapat memberikan rasa keadilan, menciptakan kepastian hukum dalam masyarakat dan memberikan kemanfaatan bagi anggota masyarakat. Pada dasarnya masyarakat Indonesia tahu dan paham hukum, tetapi secara sadar pula mereka masih melakukan perbuatanperbuatan melanggar hukum.

Dalam hal ini, sesuai dengan filosofi hukum bahwa satu- satunya sumber hukum dan kekuatan mengikatnya adalah kesadaran hukum masyarakat. Dalam hal ini, perasaan dan keyakinan hukum individu di dalam masyarakat merupakan pangkal tolak membangun kesadaran hukum masyarakat. Demikian halnya dengan kesadaran terhadap berbagai peristiwa hukum lainnya, seperti membayar pajak sebagai bagian dari kewajiban warga negara. 


\subsection{Kesadaran Pajak Warganegara}

Membangun kesadaran wajib pajak ini tidak hanya menjadi tanggungjawab mutlak Direktorat Jenderal Pajak, melainkan juga menjadi tugas dan tanggungjawab institusi pendidikan, terutama Pendidikan Tinggi. Oleh karena itu, ada beberapa regulasi yang mengatur tentang kewajiban Pendidikan Tinggi untuk meninternalisasikan kesadaran pajak ini kepada mahasiswanya. Nota Kesepahaman Menteri Keuangan dengan Menteri Riset, Teknologi, dan Pendidikan Tinggi Nomor MoU-4/MK.03/2016 dan Nomor 7/M/NK/2016, tentang Peningkatan Kerja Sama Perpajakan dan Perjanjian Kerja Sama antara Direktorat Jenderal Pajak dengan Direktorat Jenderal Pembelajaran dan Kemahasiswaan Nomor KEP48/PJ/2016 dan Nomor 001/B1/PKS/2016, tentang Peningkatan Kesadaran Pajak Melalui Pembelajaran dan Kemahasiswaan di Pendidikan Tinggi.

Oleh karena itu, dalam membangun kesadaran mahasiswa tentang pajak ini adaalah dengan memposisikan mereka tidak hanya sebagai objek pajak semata, melainkan juga sebagai subjek. Defenisi pajak sendiri sebagai salah satu bentuk pemenuhan kewajiban warga negara memiliki unsur- unsur sebagai berikut:

1. Pajak dipungut berdasarkan undangundang., dimana asas ini sesuai dengan perubahan ketiga Undang Undang Dasar Republik Indonesia Tahun 1945 Pasal 23 A yang menyatakan, "Pajak dan pungutan lain yang bersifat memaksa untuk keperluan negara diatur dalam undang-undang".

2. Tidak mendapatkan jasa timbal balik (kontraprestasi) yang dapat ditunjukkan secara langsung, misalnya orang yang taat membayar pajak, secara tidak langsung akan menerima manfaat dalam bentuk seperti rasa aman karena mendapat perlindungan negara. Perlindungan negara didapatkan karena negara mampu membiayai operasional kemanan (baik dari institusi Polri maupun TNI) yang didapat dari uang pajak yang dibayarkan.

3. Pemungutan pajak diperuntukkan bagi keperluan pembiayaan umum pemerintah dalam rangka menjalankan fungsi pemerintahan, baik rutin maupun pembangunan.

4. Pemungutan pajak dapat dipaksakan, diamana pajak dapat dipaksakan apabila wajib pajak tidak memenuhi kewajiban perpajakan dan dapat dikenakan sanksi sesuai peraturan perundang-undangan.

5. Selain fungsi budgeter (anggaran), yaitu fungsi mengisi Kas Negara/Anggaran Negara yang diperlukan untuk menutup pembiayaan penyelenggaraan pemerintahan, pajak juga berfungsi sebagai alat untuk mengatur atau melaksanakan kebijakan negara dalam sektor ekonomi dan sosial (fungsi mengatur/regulatif) (Tim Edukasi Perpajakan Direktorat Jenderal Pajak, 2016:14-15).

Menurut Pasal 1 angka (1) Undang Undang Nomor 6 Tahun 1983 tentang Ketentuan Umum dan Tata Cara Perpajakan sebagaimana telah diubah beberapa kali terakhir dengan Undang Undang Nomor 16 Tahun 2009 bahwa Pajak merupakan sebuah terminologi yang mengundang beragam opini, persepsi, dan pemikiran di sebagian besar masyarakat. Hal ini terjadi karena beberapa faktor, yaitu Pertama, faktor ketidaktahuan tentang apa yang dimaksud dengan pajak dan untuk apa pajak itu dipungut, sehingga menimbulkan opini yang beragam. Kedua, kecurigaan yang ditimbulkan oleh pihak-pihak tertentu terhadap pemungutan pajak yang dianggap rawan untuk diselewengkan oleh pihak pemungut pajak. Hal tersebut menimbulkan pemikiran untuk tidak mau menjalankan kewajiban sebagai pembayar pajak. Ketiga, anggapan bahwa pajak itu memberatkan sehingga menimbulkan berbagai cara atau strategi untuk menghindari pembayaran pajak. Keempat, menyadari pentingnya 
urgensi pajak bagi keberlangsungan hidup berbangsa, bermasyarakat, dan bernegara.

Faktor-faktor penyebab tersebut mengandung implikasi yang berbeda-beda, sehingga diperlukan penanganan dan penanggulangan yang berbeda pula. Implikasi Pertama, terkait dengan ketidaktahuan tentang apa yang dimaksud dengan pajak dapat ditanggulangi dengan cara penyuluhan dan pendidikan kesadaran perpajakan yang menjelaskan tentang apa manfaat pajak bagi kehidupan bermasyarakat, berbangsa, dan bernegara. Implikasi Kedua, terkait dengan kecurigaan adanya penyelewengan pemungutan pajak dapat ditanggulangi dengan akuntabilitas sebagai bentuk pertanggungjawaban aparatur negara, disertai sanksi yang tegas terhadap petugas yang melakukan penyelewengan, sehingga lembaga pemungut pajak bersih dari oknum yang tidak bertanggung jawab. Implikasi Ketiga, terkait dengan pihak yang melakukan strategi menghindari pembayaran pajak dapat dilakukan dengan penegakan hukum dan sanksi yang tegas (punishment) terhadap para pengemplang pajak, disertai penghargaan (reward) terhadap pembayar pajak yang setia dalam menunaikan kewajibannya pada negara. Faktor keempat merupakan sebuah kondisi ideal, karena masyarakat pembayar pajak sudah memiliki kesadaran tentang perlunya pajak (Tim Edukasi Perpajakan Direktorat Jenderal Pajak, 2016:28-29).

Oleh karena itu, kondisi ideal itu perlu dipelihara dan dikembangkan melalui berbagai cara dan strategi yang tepat, sehingga pelanggaran dalam masalah perpajakan dapat diminimalisir Campur tangan pemerintah dalam menerapkan distribusi pajak sangat diperlukan dan mengandung dua dimensi. Pertama, sifat memaksa yang diperlukan untuk memberikan sanksi kepada warga negara yang mampu agar menunaikan kewajibannya membayar pajak sesuai dengan hukum yang berlaku. Kedua, sifat kerelaan dari warga negara sebagai implementasi nilai kebersamaan, kepedulian, saling berbagi, dan kasih sayang sesama warga negara (Tim Edukasi Perpajakan Direktorat Jenderal Pajak, 2016:28-29).

Kesadaran sebagai suatu gejala psikologis bagi seseorang Salah satu contoh kewajiban warga negara terpenting saat ini adalah kewajiban membayar pajak (Pasal 23A, UUDRI 1945). Hal ini dikarenakan saat ini pajak merupakan sumber penerimaan negara terbesar dalam membiayai pengeluaran negara dan pembangunan. Tanpa adanya sumber pendapatan pajak yang besar, maka pembiayaan pengeluaran negara akan terhambat. Pajak menyumbang sekitar $74,63 \%$ pendapatan negara. Oleh karena itu, membayar pajak adalah contoh kewajiban warga negara yang nyata di era pembangunan seperti sekarang ini (Belmawa, 2016:121). Dengan masuknya pendapatan pajak dari warga negara maka pemerintah negara juga akan mampu memenuhi hak warga negara, yakni hak mendapatkan penghidupan yang layak bagi kemanusiaan sebagaimana diamanatkan pasal 27 ayat (2) Undang Undang Dasar Republik Indonesia Tahun 1945.

Pajak yang dibayarkan oleh warga negara merupakan devisa negara untuk menunjang pembangunan nasional yang berkelanjutan (sustainable). Namun demikian, kesadaran wajib pajak dalam membayar pajak dipengaruhi oleh beberapa faktor, yaitu pengetahuan dan pemahaman akan peraturan perpajakan, pelayan fiskus yang berkualitas, dan persepsi wajib pajak atas efektivitas sistem perpajakan. Sebagian wajib pajak tidak mengerti tentang peraturan perpajakan yang ada (Rahman Adi Nugroho dan Zulaikha, 2012:1). Diterbitkannya Undang Undang Nomor 6 Tahun 1983 yang telah diubah dengan Undang Undang Nomor 28 Tahun 2007 tentang Ketentuan Umum dan Tata Cara Perpajakan (KUP) dikenal istilah Self 
Assessment System (SAS) yang memberikan kepercayaan kepada wajib pajak untuk menghitung, membayar, dan melaporkan sendiri pajak terutangnya. Diharapkan pendekatan ini, selain bergantung pada kesadaran dan kejujuran wajib pajak, pengetahuan teknis perpajakan yang memadai juga memegang peran penting agar wajib pajak dapat melaksanakan kewajiban perpajakannya dengan baik dan benar karena melalui sistem ini, setiap wajib pajak di wajibkan mengisi sendiri dan menyampaikan Surat Pemberitahuan Tahunan (SPT) dengan benar, lengkap, dan jelas.

Oleh karena itu, kesadaran membayar pajak memiliki arti keadaan dimana seseorang mengetahui, memahami, dan mengerti tentang cara memabayar pajak. Apabila wajib pajak memiliki pengetahuan dan pemahaman tentang peraturan perpajakan serta pelayanan yang berkualitas terhadap wajib pajak maka akan timbul kesadaran akan membyar pajak. Kesadaran membayar pajak karena wajib pajak memiliki kewajiban untuk membayar pajak. Pajak yang mereka bayar digunakan oleh pemerintah untuk membiayai pelayanan publik dan pembangunan nasional.

Salah satu upaya dalam meningkatkan penerimaan pajak adalah dengan memberikan suatu pelayanan yang bermutu terhadap Wajib Pajak selaku pelanggan. Sesuai pasal 17 C KUP Jis KMK Nomor 544/KMK.04/2000 Direktorat Jenderal Pajak telah mengeluarkan kriteria Wajib Pajak Patuh. Wajib Pajak Patuh adalah Wajib Pajak yang ditetapkan oleh Direktorat Jenderal Pajak sebagai Wajib Pajak yang memenuhi kriteria tertentu yang dapat diberikan pengembalian pendahuluan atas kelebihan pembayaran pajak.

Dengan demikian, pengertian wajib pajak patuh bisa disimpulkan menjadi dua, yaitu:

1. Kepatuhan formal adalah suatu keadaan di mana wajib pajak memenuhi kewajiban secara formal sesuai dengan ketentuan dalam Undang-Undang Perpajakan.

2. Kepatuhan material adalah suatu keadaan di mana wajib pajak memenuhi semua ketentuan material perpajakan, yakni sesuai dengan isi dan jiwa UndangUndang perpajakan. Kepatuhan material dapat juga meliputi kepatuhan formal.

Oleh karena itu, kesadaran membayar pajak dapat diartikan sebagai suatu bentuk sikap moral yang memberikan sebuah kontribusi kepada negara untuk menunjang pembangunan negara dan berusaha untuk mentaati semua peraturan yang telah ditetapkan oleh negara serta dapat dipaksakan kepada Wajib Pajak. Meningkatnya pengetahuan perpajakan masyarakat melalui pendidikan perpajakan baik formal maupun non formal akan berdampak positif terhadap kesadaran wajib pajak untuk membayar pajak. Karakteristik wajib pajak yang dicerminkan oleh kondisi budaya, sosial, dan ekonomi akan dominan membentuk perilaku wajib pajak yang tergambar dalam tingkat kesadaran mereka dalam membayar pajak.

Dinamika pajak yang diperlukan dalam kehidupan bermasyarakat, berbangsa dan bernegara didorong oleh beberapa faktor.

Pertama, pembayar pajak memiliki kesadaran penuh dalam melaksanakan kewajibannya ketika hasil-hasil pembangunan dapat dirasakan langsung dalam kehidupan sosial.

Kedua, pembayar pajak merasa dirugikan sebagai pihak yang aktif membayar pajak manakala menyaksikan maraknya korupsi yang menguras uang negara, yang salah satunya berasal dari pajak.

Ketiga, pembayar pajak merasa optimis dalam melaksanakan 


$\begin{array}{lrr}\text { kewajibannya } & \text { manakala } \\ \text { pemerintah memperlihatkan } & \text { kinerja yang baik berupa } \\ \text { keningkatan kesejahteraan } & \text { kan } \\ \text { masyarakat dan keadilan } \\ \text { dalam berbagai } & \text { sendi } \\ \text { kehidupan sosial. }\end{array}$

Keempat, pembayar pajak merasa pesimis dalam melaksanakan kewajibannya, sehingga berupaya untuk menghindari kewajibannya tersebut manakala menyaksikan merosotnya kesejahteraan masyarakat, tingginya angka penggangguran, meningkatnya kriminalitas, dan berbagai patologi sosial lainnya (Tim Edukasi Perpajakan Direktorat Jenderal Pajak, 2016:45-46).

Oleh karena itu, campur tangan pemerintah dalam menerapkan distribusi pajak sangat diperlukan dan mengandung dua dimensi. Pertama, sifat memaksa (heteronom) yang diperlukan untuk memberikan sanksi kepada wajib pajak agar menunaikan kewajibannya sebagai warga negara yang baik dan taat hukum. Kedua, sifat kerelaan dari wajib pajak sebagai implementasi nilai kebersamaan, kepedulian, saling berbagi, kasih sayang sesama warga negara. Kedua dimensi itu tidak berdiri sendiri, melainkan saling melengkapi secara simbiosismutualis (Tim Edukasi Perpajakan Direktorat Jenderal Pajak, 2016:47).

\section{SIMPULAN}

Kesadaran hukum masyarakat dapat dilihat dalam dua konteks pengertian, yaitu secara sempit dan luas. Kesadaran hukum masyarakat dalam arti sempit dimaknai sebagai pengetahuan tentang perintah dan larangan tindakan hukum tertentu, sedangkan dalam arti luas dimaknai kemantapan hati untuk mematuhi segala peraturan hukum yang berlaku (kesadaran afeksi).

3. Pajak yang dibayarkan oleh warga negara merupakan devisa negara untuk menunjang pembangunan nasional yang berkelanjutan (sustainable). Namun demikian, kesadaran wajib pajak dalam membayar pajak dipengaruhi oleh beberapa faktor, yaitu pengetahuan dan pemahaman akan peraturan perpajakan, pelayan fiskus yang berkualitas, dan persepsi wajib pajak atas efektivitas sistem perpajakan. 


\section{DAFTAR PUSTAKA}

Achmad, Ali. 2009. Menguak Teori Hukum (Legal Theory) dan Teori Peradilan (Judicial Prudence) termasuk Interpretasi Undang Undang (Legis Prudence). Jakarta: kencana.

Bakry, Ms. Noor. 2009. Pendidikan Kewarganegaraan. Yogyakarta: Pustaka Pelajar.

Bisri, Ilham. 2004. Sistem Hukum Indonesia. Jakarta: Grafindo Persada.

Dirjen Belmawa. 2016. Pendidikan Kewarganegaraan untuk Perguruan Tinggi. Cet. 1. Jakarta: Dirjen Belmawa Kemenristekdikti.

Ismawan. 2001. Memahami Reformasi Perpajakan. Jakarta: PT. Elex Media Komputindo.

Kepmendiknas No. 232/U/2000, tentang Pedoman Penyusunan Kurikulum Pendidikan Tinggi dan Penilaian Hasil Belajar Mahasiswa.

Kepmendiknas No.045/U/2002 tentang Kurikulum Inti Pendidikan Tinggi menetapkan bahwa Pendidikan Agama, Pendidikan Pancasila, dan Pendidikan Kewarganegaraan merupakan kelompok Mata Kuliah Pegembangan Kepribadian.

Keputusan Dirjen Dikti Depdiknas No. 43/Dikt i/Kep/2006 tentang Rambu Rambu Pelaksanaan Pembelajaran Kelompok Mata Kuliah Pengembangan Kepribadian di Perguruan Tinggi.

KUP Jis KMK Nomor 544/KMK.04/2000 Direktorat Jenderal Pajak tentang Kepatuhan Wajib Pajak.

Nota Kesepahaman Menteri Keuangan dengan Menteri Riset, Teknologi, dan Pendidikan Tinggi Nomor MoU-4/MK.03/2016 dan Nomor 7/M/NK/2016 tentang Peningkatan Kerja Sama Perpajakan.

Nugroho, Rahman Adi dan Zulaikha. 2012. Faktor Faktor yang Mempengaruhi Kemauan untuk Membayar Pajak dengan Kesadaran Membayar Pajak sebagai Variabel Intervening. (Studi kasus wajib pajak orang pribadi yang melakukan pekerjaan bebas yang terdaftar di KPP Pratama Semarang Tengah Satu). Diponegoro Journal of Accounting, Volume 1, Nomor 2, Tahun 2012. Semarang: UNDIP.

Perjanjian Kerja Sama antara Direktorat Jenderal Pajak dengan Direktorat Jenderal Pembelajaran dan Kemahasiswaan Nomor KEP-48/PJ/2016 dan Nomor 001/B1/PKS/2016, tentang Peningkatan Kesadaran Pajak Melalui Pembelajaran dan Kemahasiswaan di Pendidikan Tinggi.

Rahardjo, Satjipto. 1991. Ilmu Hukum. Bandung: Citra Aditya Bakti.

Soekanto,Soerjono. 2005. Pokok Pokok Sosiologi Hukum. Jakarta: PT. Raja Grafindo Persada.

Saifullah. 2006. Refleksi Sosiologi Hukum. Bandung: PT. Refika Aditama.

Soekanto, Soerjono. 2013. Sosiologi suatu Pengantar. Jakarta: Rajawali Press. 
Tim Edukasi Perpajakan Direktorat Jenderal Pajak. 2016. Materi Terbuka Kesadaran Pajak untuk Perguruan Tinggi. Jakarta: Dirjen Pajak Kemenkeu RI.

Undang Undang Nomor 28 Tahun 2007 tentang Ketentuan Umum dan Tata Cara Perpajakan $(K U P)$.

Undang Undang Nomor 16 Tahun 2009 tentang Ketentuan Umum dan Tata Cara Perpajakan.

Usman, Atang Hermawan. 2014. Kesadaran Hukum Masyarakat dan Pemerintah sebagai Faktor Tegaknya Negara Hukum di Indonesia. Jurnal Wawasan Hukum, Volume 30, Nomor 1, Edisi Februari 2014. Bandung: Polda Jabar.

Undang Undang Dasar Republik Indonesia Tahun 1945.

Warasih, Esmi. 2005. Pranata Hukum: Sebuah Telaah Sosiologi. Semarang: PT. Suryandaru Utama.

Yuswandi, Ali. 1995. Penuntutan, Hapusnya Kewenangan Menuntut dan Menjalankan Pidana. Jakarta: CV. Pedoman Ilmu Jaya. 